\title{
Analysis of the Content of Character Values and the Learning Practice of Character Values in Pancasila and Citizenship Education Texts Book
}

\author{
Jawatir Pardosi \\ Pancasila and Citizenship Education Program \\ Teacher Training and Education Faculty of \\ Mulawarman University \\ Samarinda, Indonesia \\ pardo_si@yahoo.com
}

\author{
Rifan Azzola \\ Pancasila and Citizenship Education Program \\ Teacher Training and Education Faculty of \\ Mulawarman University \\ Samarinda, Indonesia \\ rifanazzola@gmail.com
}

\begin{abstract}
One way to support the implementation of character education is the provision of textbooks for students. The studies were aimed to analyze the content of character values in Pancasila and Citizenship Education text book in 2013 Curriculum and to describe the learning practice of character values in Pancasila and Citizenship textbook. This research was conducted at the State High School 5 Samarinda. The Study used snowball sampling technic. Initial respondents were 9 people consisting of: two Pancasila and Citizenship Education teachers, one School Principal, three teachers and three students. The data collection techniques are observation, interview and documentation. Data analysis technique is using qualitative data analysis techniques presented in the form of descriptions and tables. The results of this study showed that: (1) all of character values (18 pieces) contained in the textbook; (2) the highest percentage of character values are tolerance, creative and responsibility (all three are $9 \%$ ) and the lowest percentage is independent $(2 \%)$. Each character value is presented in a number of different pages. The responsibility character value is $\mathbf{1 9}$ pages, while the independence value is only 1 page; (3) character learning practices are carried out with three patterns, namely: (a) patterns integrated with (curricular) learning, (b) co-curricular, and extracurricular. In addition, the teacher's role model is also important to instill character values in students.
\end{abstract}

Keywords: character, textbook, Pancasila and Citizenship education

\section{INTRODUCTION}

Character is a way of thinking and behaving that characterizes every individual in the association of others, both in the family, as well as in the scope of the nation and state. Character is behavior or manner of someone who is reflected in a person's attitude or behavior. Many things can affect people's behavior so that between one people with another is different. Among the factors that can influence a person's behavior are the environment of residence and school education. That is why many people demand the intensity and implementation of character education in formal educational institutions. One of the things developed to realize these goals is the holding of a system in the form of books.

Textbooks will often be read by students, so textbooks can influence student development, including their character. Therefore, textbooks can be said as a strategic learning media to develop student character. Textbooks that contain positive things, including good character, influence the development in a positive direction in students [1].

This studies were aimed: (1) to analyze the content of character values in Pancasila and Citizenship Education text book in 2013 Curriculum, and (2) to describe the learning practice of character values in Pancasila and Citizenship Education textbook.

According to Online Etymology Dictionary, definition of value are (1) price equal to the intrinsic worth of a thing; (2) degree to which something is useful or estimable; (3) from Old French value "worth, price, moral worth; (4) from Latin valere "be strong, be well. Values are principles, fundamental convictions, and ideals, standards of life which act as general guide to behavior or as a reference point in decision making [2]. Values are beliefs about what is right and what is wrong and what is important in life. Value literally means something that has a price, precious, dear and worthwhile; one is ready to sacrifice for [3].

The term character starts from the Latin "character, kharassein, kharax", which means "tools for making, to engrave, and pointed stake". This word is used in the French "caractere" [4].Merriam Webster explain some definitions of character, namely: (1) one of the attributes or features that make up and distinguish an individual, (2) features used to separate distinguishable things into categories also: a group or kind so separated advertising of a very primitive character, (3) the aggregate of distinctive characteristics of a breed, strain, or type a wine of great character [5].

According to Cronbach character is not an accumulation of separate habits and ideas [4]. Character is an aspect of the personality. Beliefs, feelings, and actions, are linked; to change character is to reorganize the personality. Tiny lessons on principles of good conduct will not be effective if they cannot be integrated with the person's system of beliefs about himself, about others, and about the good community.

Different from Cronbach, Lickona divides character into three interrelated fields namely moral knowing, moral feeling, and moral behavior. Therefore, good character Contains three competencies, namely knowing the good, desiring the good, and doing the good so that in turn it will become habits of the mind, habits of heart and habits of action [6].

The Ministry of National Education of the Republic of Indonesia formulated 18 aspects of character values as a 
reference in the implementation of character education in schools, namely: religious, honest, tolerance, discipline, hard work, creative, independent, democratic, curiosity, national spirit, love of the motherland, respect for achievement, communicative/friendly, peace-loving, fond of reading, caring for the environment, caring socially, and being responsible [7].

A textbook is a book used for the study of a subject. People use a textbook to learn facts and methods about a certain subject. Textbooks sometimes have questions to test the knowledge and understanding of the learner [6].

According to the Regulation of National Education Minister No. 11 of 2005, textbooks are mandatory reference books for use in schools that contain learning materials in order to increase faith and piety, character and personality, the ability to master science and technology, sensitivity and aesthetic abilities, physical potential and health arranged based education national standard [8].

In Cunningsworth's view the roles of textbooks are identified as: -an effective resource for self-directed learning and self-study; -a valuable resource for presentation material (written and spoken); -a source of ideas and activities for learner practice and communicative interaction;- a reference source for students; -a syllabus; -a support for less experienced teachers to gain confidence and demonstrate new methodologies [9].

The purpose of Pancasila and Citizenship Education is that students are able to: 1 ) display characters that reflect the values and moral values and morals of Pancasila personally and socially; 2) having a constitutional commitment supported by a positive attitude and understanding of the 1945 Constitution of the Republic of Indonesia; 3) think critically, rationally, and creatively and have a national spirit and love for the motherland imbued with Pancasila values, the 1945 Constitution of the Republic of Indonesia, the spirit of Unity in Diversity, and the commitment of the Unitary Republic of Indonesia, and 4) participate actively, intelligently, and responsibly as members of the community, the nation's shoots, and citizens in accordance with their dignity and dignity as creatures created by God who lives together in various socio-cultural settings.

The scope of Pancasila and Citizenship Education according to the Regulation of Minister of Education and Culture No. 69 of 2013, including: 1) Pancasila as the basis of state, ideology, and nation ways of life; 2) The 1945 Constitution as a written legal basis which constitutes constitutional foundation of life in a society, nation and state; 3) Unitary state of the Republic of Indonesia, as a final agreement on the form of the Republic of Indonesia; 4) Unity in diversity, as a form of a unity philosophy which underlies and colors the diversity of life in a society, nation and state [10].

The Pancasila and Citizenship Education are values, morals/character education, and Indonesian citizenship that are not congruent with civic education in the USA, citizenship education in the UK, "talimatul muwatanah" in Middle Eastern countries, education civic as in Latin America. Pancasila and Citizenship Education as a vehicle for the education of values, morals/character of Pancasila and the development of psychosocial capacities of Indonesian citizenship are very coherent (continuous and integrated) with a commitment to develop the nation's dignified character and civilization and the realization of democratic and responsible citizens as stipulated in Article 3 of the Law No.20 of 2003.

\section{METHOD}

This study uses descriptive qualitative research methods, namely identifying, describing and describing the character values contained in textbooks and learning practices. The location of the research was at State Senior High School 5 Samarinda. The study used snowball sampling technique. The number of respondents in the field can grow until data completeness is achieved. The initial sample consisted of: two Pancasila and Citizenship Education teachers, one School Principal, three teachers and three students.

The data collection techniques are observation, interview and documentation. Data analysis technique is using qualitative data analysis techniques developed, namely the stage of data reduction, data display, conclusion drawing verification. In-depth interviews were conducted with respondents in accordance with the objectives of the study and in accordance with the role of the respondents [11].

\section{RESULTS AND DISCUSSION}

\section{A. Content Analysis of Character Values in Pancasila and Citizenship Education Textbook}

Based on Table 1, the character values of tolerance, creative and responsibility are the highest percentage, which is equal to $9 \%$ or discussed in 6 chapters. The total number of chapters from the Pancasila and Citizenship Education textbook at Class XI are 6 chapters. Therefore, every chapter, the material values of tolerance, creativity, and responsibility are always discussed.

TABLE I. FREQUENCY OF APPEARANCE OF CHARACTER VALUES ACCORDING TO THE TEXTBOOK CHAPTER

\begin{tabular}{|c|c|c|c|c|c|c|c|c|c|}
\hline \multirow{2}{*}{ No } & \multirow{2}{*}{ Character Values } & \multicolumn{6}{|c|}{ Chapter } & \multirow{2}{*}{$\begin{array}{c}\text { Num- } \\
\text { ber }\end{array}$} & \multirow{2}{*}{$\%$} \\
\hline & & 1 & 2 & 3 & 4 & 5 & 6 & & \\
\hline 1 & Religious & $\checkmark$ & $\checkmark$ & - & - & $\checkmark$ & $\checkmark$ & 4 & 6 \\
\hline 2 & Honest & $\checkmark$ & $\checkmark$ & $\checkmark$ & & & $\checkmark$ & 4 & 6 \\
\hline 3 & Tolerance & $\checkmark$ & $\checkmark$ & $\checkmark$ & $\checkmark$ & $\checkmark$ & $\checkmark$ & 6 & 9 \\
\hline 4 & Discipline & $\checkmark$ & - & - & - & $\checkmark$ & - & 2 & 3 \\
\hline 5 & Hard Work & $\checkmark$ & $\checkmark$ & $\checkmark$ & - & - & - & 3 & 5 \\
\hline 6 & Creative & $\checkmark$ & $\checkmark$ & $\checkmark$ & $\checkmark$ & $\checkmark$ & $\checkmark$ & 6 & 9 \\
\hline 7 & Independent & - & - & - & - & - & $\checkmark$ & 1 & 2 \\
\hline 8 & Democratic & $\checkmark$ & $\checkmark$ & $\checkmark$ & - & - & - & 3 & 5 \\
\hline 9 & Curiosity & $\checkmark$ & $\checkmark$ & $\checkmark$ & - & - & $\checkmark$ & 4 & 6 \\
\hline 10 & National Spirit & - & - & - & $\checkmark$ & & $\checkmark$ & 2 & 3 \\
\hline 11 & Love of the Motherland & - & - & - & - & $\checkmark$ & $\checkmark$ & 2 & 3 \\
\hline 12 & Appreciate the Achievements & $\checkmark$ & $\checkmark$ & $\checkmark$ & $\checkmark$ & - & - & 4 & 6 \\
\hline 13 & Communicative & $\checkmark$ & $\checkmark$ & $\checkmark$ & - & $\checkmark$ & $\checkmark$ & 5 & 8 \\
\hline 14 & Peaceful love & - & - & - & $\checkmark$ & $\checkmark$ & - & 2 & 3 \\
\hline 15 & Like to read & $\checkmark$ & $\checkmark$ & $\checkmark$ & - & $\checkmark$ & - & 4 & 6 \\
\hline 16 & Social Care & $\checkmark$ & $\checkmark$ & $\checkmark$ & $\checkmark$ & & $\checkmark$ & 5 & 8 \\
\hline 17 & Environmental Care & - & - & $\checkmark$ & - & - & $\checkmark$ & 2 & 3 \\
\hline 18 & Responsibility & $\checkmark$ & $\checkmark$ & $\checkmark$ & $\checkmark$ & $\checkmark$ & $\checkmark$ & 6 & 6 \\
\hline \multicolumn{2}{|r|}{ Total } & 13 & 12 & 12 & 7 & 9 & 12 & 65 & 100 \\
\hline \multicolumn{10}{|c|}{ Remarks: } \\
\hline \multicolumn{10}{|c|}{ Harmonization of Human Rights and Obligations in the Pancasila Perspective } \\
\hline & \multicolumn{9}{|c|}{ : System and Dynamics of Pancasila Democracy } \\
\hline Chap & \multicolumn{9}{|c|}{ The Law and Judicial System in Indonesia } \\
\hline Chap & \multirow{2}{*}{\multicolumn{9}{|c|}{$\begin{array}{l}\text { Dynamics of Indonesia's Role in World Peace } \\
\text { Beware of Threats to the Unitary State of the Republic of Indonesia }\end{array}$}} \\
\hline Chap & \multicolumn{4}{|c|}{$\begin{array}{l}\text { Beware of Threats to the Unitary State of the Republic of Indonesia } \\
\text { Strengthening Unity and National Unity in the Unitary State of the Republic of }\end{array}$} & & & & & \\
\hline Chap & \multicolumn{9}{|c|}{ Strengthening Unity and National Unity in the Unitary State of the Republic of } \\
\hline
\end{tabular}




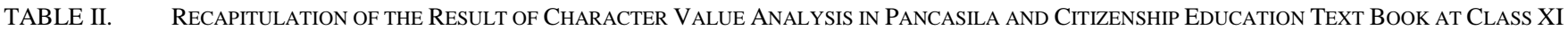

\begin{tabular}{|c|c|c|c|}
\hline No. & Values & Indicators & Pages \\
\hline 1 & Religious & $\begin{array}{l}\text { a. Grateful for the superiority of humans as creators and master compared to other creatures } \\
\text { b. Give thanks to God for being a citizen of the nation Indonesia } \\
\text { c. Feel the power of God who has created order in the universe } \\
\text { d. Feel the greatness of God with the diversity of religions in the world } \\
\text { e. Admire the greatness of God through various subjects in various subjects }\end{array}$ & $\begin{array}{c}3,24 \\
144,174,3,24 \\
8,14 \\
5,36,38,147\end{array}$ \\
\hline 2 & Honest & $\begin{array}{l}\text { a. Carry out tasks according to academic rules applies in school } \\
\text { b. Strictly mention the advantages and its advantages of a subject } \\
\text { c. Want to talk about problems him in accepting opinions her friend } \\
\text { d. Express opinions about something according to what he believes } \\
\text { e. Pay for items purchased with honest } \\
\text { f. Return borrowed items or found in a public place }\end{array}$ & $\begin{array}{c}6,115 \\
186 \\
37,68,71,91,95\end{array}$ \\
\hline 3 & Tolerance & $\begin{array}{l}\text { a. Provide an opportunity for friends to dissent } \\
\text { b. Friendly with other friends without distinction of religion, race, and ethnicity } \\
\text { c. Want to listen to an opinion expressed a friend of his culture } \\
\text { d. Want to accept a different opinion from classmates. }\end{array}$ & $\begin{array}{c}15,143 \\
106,169,193 \\
72,73,169\end{array}$ \\
\hline 4 & Discipline & $\begin{array}{l}\text { a. Always meticulous and orderly in doing task } \\
\text { b. Orderly in applying the rules writing in a writing } \\
\text { c. Obey laboratory work procedures and problem observation procedures social } \\
\text { d. Comply with the study schedule that you have set yourself } \\
\text { e. Orderly in applying the rules writing for scientific papers }\end{array}$ & 31 \\
\hline 5 & Hard Work & $\begin{array}{l}\text { a. Work on tasks carefully and neatly. } \\
\text { b. Use time effectively to complete assignments in class and outside class } \\
\text { c. Always try to find information about subject matter from various sources }\end{array}$ & $\begin{array}{c}24,65,73,105 \\
7,19,20,83\end{array}$ \\
\hline 6 & Creative & $\begin{array}{l}\text { a. Propose a new thought about a subject } \\
\text { b. Apply the law / theory / principle that is being studied in aspects of people's lives }\end{array}$ & $\begin{array}{l}2,13,51,86,131,158 \\
183 \\
28,29,70,71,107,198\end{array}$ \\
\hline 7 & Independent & $\begin{array}{l}\text { a. Looking for resources in the library to complete Schoolwork without the help of a librarian } \\
\text { b. Translate Indonesian sentences into a foreign language or vice versa }\end{array}$ & 186 \\
\hline 8 & Democratic & $\begin{array}{l}\text { a. Familiarize yourself in deliberation with friends } \\
\text { b. Accept defeat in a sincere election } \\
\text { c. Express opinions about friends who become leaders } \\
\text { d. Give an opportunity for friends who are leaders to work }\end{array}$ & $\begin{array}{c}15,61,69,117 \\
51 \\
61,69 \\
\end{array}$ \\
\hline 9 & Curiosity & $\begin{array}{l}\text { a. Ask or read sources outside of textbooks about material related to the lesson } \\
\text { b. Read or discuss natural phenomena that just happened } \\
\text { c. Read or discuss some new natural, social, cultural, economic, political and technological events that have } \\
\text { just been heard }\end{array}$ & $\begin{array}{l}19,41,78,87,116 \\
\quad 33,74,116 \\
\quad 20,50,181\end{array}$ \\
\hline 10 & National Spirit & $\begin{array}{l}\text { a. Take part in the commemoration committee Heroes' Day and the Proclamation of Independence } \\
\text { b. Expressing thoughts and attitudes towards the conflict between the Indonesian people and other countries } \\
\text { c. Expressing attitudes and actions regarding Indonesia's relations with other countries are in trouble political, } \\
\text { economic, social and cultural }\end{array}$ & $\begin{array}{l}141,202 \\
124,125\end{array}$ \\
\hline 11 & $\begin{array}{l}\text { Love of the } \\
\text { Motherland }\end{array}$ & $\begin{array}{l}\text { a. Expressing attitude about Indonesian geographical conditions } \\
\text { b. Expressing attitudes and concerns towards cultural and artistic diversity in Indonesia } \\
\text { c. Expressing attitudes and concerns regarding the cultural wealth of the Indonesian nation } \\
\text { d. A sense of pride and care for various excellent Indonesian products in agriculture, fisheries, flora and } \\
\text { fauna } \\
\text { e. Sense of pride for various superior products of the Indonesian people in the fields of industry and } \\
\text { technology. }\end{array}$ & $\begin{array}{l}145,179,187,201 \\
177,197 \\
145,178 \\
161,189 \\
169,201\end{array}$ \\
\hline 12 & $\begin{array}{l}\text { Appreciate the } \\
\text { Achievements }\end{array}$ & $\begin{array}{l}\text { a. Diligently study for high achievers } \\
\text { b. Train hard to be a winner in various sports and arts activities at school } \\
\text { c. Appreciate the hard work of teachers, principals, and other personnel } \\
\text { d. Appreciate parents' efforts to develop their various potentials through education and other activities } \\
\text { e. Appreciate the work of leaders in the welfare of society and the nation. } \\
\text { f. Appreciate the findings that have been produced by humans in the fields of science, technology, social, } \\
\text { culture, and art }\end{array}$ & $\begin{array}{l}1,36,118 \\
115 \\
15\end{array}$ \\
\hline 13 & Communicative & $\begin{array}{l}\text { a. Give opinions in group work in class } \\
\text { b. Give and listen to opinions in class discussions } \\
\text { c. Active in class social and cultural activities } \\
\text { d. Active in organizational activities in schools } \\
\text { e. Talk with teachers, school principals, and school personnel the other }\end{array}$ & $\begin{array}{l}70,117,168 \\
83 \\
33,74,116,142,171,203\end{array}$ \\
\hline 14 & Peaceful love & $\begin{array}{l}\text { a. Participate in various peace-loving activities } \\
\text { b. Communicate with friends in the country } \\
\text { c. Participate in maintaining school safety }\end{array}$ & $\begin{array}{c}140 \\
141,144 \\
\end{array}$ \\
\hline 15 & Like to read & $\begin{array}{l}\text { a. Read books or scientific writing, literature, art, culture, technology, and humanities } \\
\text { b. Read books or writings about nature, social, culture, art, and technology } \\
\text { c. Reading the newspaper }\end{array}$ & $\begin{array}{c}37,49,147 \\
1,93 \\
41\end{array}$ \\
\hline 16 & Social Care & $\begin{array}{l}\text { a. Design and carry out various social activities } \\
\text { b. Respect school officials } \\
\text { c. To help friends who are in need of help } \\
\text { d. Donating blood }\end{array}$ & $\begin{array}{c}6,70,107,140 \\
115 \\
15,32,198\end{array}$ \\
\hline 17 & $\begin{array}{l}\text { Environmental } \\
\text { Care }\end{array}$ & a. Plan and carry out various activities prevention of environmental damage & 115,188 \\
\hline 18 & Responsibility & $\begin{array}{l}\text { a. Doing Tasks and Homework } \\
\text { b. Working on group assignments together }\end{array}$ & $\begin{array}{c}7,41,65,78,87,117,120 \\
143,154,181,204 \\
12,15,20,44,83,138 \\
166,195\end{array}$ \\
\hline
\end{tabular}


The smallest percentage is the value of independent (2\%) or discussed in only one chapter. The difference in the number of percentages is related to the intensity of learning the material value of each character. The higher of level of percentage is the higher of intensity the learning of character's value. Conversely, the lower of level of percentage is the smaller of intensity the learning of character value. Issue about tolerance lately is increasingly raised, so it is appropriate if tolerance learning has a greater portion than the other character values.

Based on Table 2, each character value is loaded in a different number of pages. The difference in the number of pages, does not indicate the intensity of learning the value of characters, but aims to make it easier for readers to find the page. Based on the number of pages, it can be seen that the most responsibility value (19 pages) follows creative (13 pages), patriotism (12 pages), curiosity and religious (11 pages) and other character values below 9 pages.

The least character values contained in the textbook pages are independence (1 page), Environmental Care (2 pages), peaceful love ( 3 pages), national spirit (4 pages) and others more than 4 pages. A small number of pages of character values do not mean that fewer characters are loaded in textbooks.

\section{B. Character Learning Practices}

Based on data obtained from respondents (the teachers of Pancasila and Citizenship Education, the Teachers, the School Principals and the Students) and documents and observations it is known that character learning practices implemented primarily are integrated with curricular learning materials. All kinds of character values (18) turned out to be contained in textbooks. However, the intensity of time and breadth of material for each character value there are differences. Character learning practices integrated with learning materials as shown in Table 2.

Beside the practice of character learning integrated with learning (curricular), the practice of character learning is carried out, namely:

(1) Habituation of daily behavior in schools, which is implemented through the enforcement of student discipline and behavioral problems, involving students to maintain classroom cleanliness and school environment, student counseling, school management for programs to strengthen the character education and mutual cooperation practices for cleanliness of the school environment and cleaning sewers to prevent the danger of flooding.

(2) Co-curricular activities, which are carried out through comparative studies to other schools to increase insight into character strengthening and visiting educational sites outside the school (historic museums, court institutions, religious institutions, and joint student tours).

(3) Extracurricular activities, which are carried out when carrying out scouting activities, student leadership training, youth Red Cross, school health efforts and flag raising troops. The results also showed that the practice of strengthening students' character was carried out through scientific work activities such as sports development activities, arts and culture, wall magazines, theater and photography. Based on the results of the interviews it was also found that the teacher model patterns were the most important elements for embed character values, so the teacher role models were part of the management program of character strengthening in their schools.

\section{CONCLUSION}

There are a total of 18 items of character values contained by the High School textbook. There is a difference in the frequency of the inclusion of character values indicating the difference in learning intensity of the character values. The higher the percentage level is the more intensive the learning of character values. Conversely, the lower the percentage level, the smaller the intensity of character learning. There are a number of different pages and the presentation of character values in the textbook. The difference in the number of pages does not indicate the amount of material character. The purpose of listing is to make it easier for readers to explore character values. Better school management is needed to include material for strengthening character education in schools. The practice of character learning places more emphasis on teacher exemplary patterns. The practice of character value learning is carried out, namely: (1) integrated with subject matter, (2) co-curricular, and (3) extracurricular.

\section{REFERENCES}

[1] M. Muslich, Teks Book Writing Dasar-dasar Pemahaman, Penulisan, dan Pemakaian Buku Teks. Yogyakarta: Ar-Ruzz Media, 2010.

[2] Online Etymology Dictionary, Retrieved from: https://www.etymonline.com/word/value, (Accessed 2019-8-20), 2019.

[3] J. Parankimalil, Value Education. Retrieved from: https://johnparankimalil.wordpress.com/2015/09/22/value-education/. (Accessed 2019-8-20), 2015.

[4] Masrukhi, "Manajemen pembelajaran pendidikan kewarganegaraan sebagai pembangun karakter: penelitian pada beberapa sekolah dasar di kota semarang," Disertasi, Program Pascasarjana Universitas Negeri Semarang, 2005.

[5] Merriam Webster, Definition of Character. Retrieved from: https://www.merriam-webster.com/dictionary/character. (Accessed 2019-7-20), 2019.

[6] T. Lickona, My Thoughts about National Character. Ithaca and London: Cornell University Press, 2003.

[7] Kementerian Pendidikan Nasional Republik Indonesia, Pengembangan Pendidikan Budaya dan Karakter Bangsa. Retrieved from: https://www.websitependidikan.com/2017/07/18-nilai-dalampendidikan-karakter-versi-kemendiknas-dan-penjelasannyalengkap.html. (Accessed 2019-7-20), 2010.

[8] Permendiknas, Peraturan Menteri Pendidikan Nasional No. 11 Tahun 2005 tentang Buku Teks, 2005.

[9] A. Cunningsworth, Choosing your coursebook, Oxford: Macmillan He-inemann ELT, 1995.

[10] Peraturan Menteri Pendidikan dan Kebudayaan No. 69 Tahun 2013 tentang Kerangka Dasar dan Struktur Kurikulum Sekolah Menengah Atas/Madrasah Aliyah.

[11] M.B. Miles, A.M. Huberman, and J. Saldana, Qualitative Data Analysis, A Methods Sourcebook, Edition 3. USA: Sage Publications. Terjemahan Tjetjep Rohindi Rohidi, UI-Press, 2004. 